\title{
Uji Aktivitas Antibakteri Sediaan Krim Anti Jerawat Ekstrak Etanol Terpurifikasi Daun Sirih (Piper betle L.) dengan Basis Vanishing Cream Terhadap Propionibacterium acne
}

\author{
Nuralifah*, Fery Indradewi Armadany, Parawansah, Aulif Pratiwi
}

Fakultas Farmasi Universitas Halu Oleo, Kampus Hijau Bumi Tridharma Anduonohu Jl. H. E. A. Mokodompit Kendari 93232

E-mail: nuralifahapt11@gmail.com

\begin{abstract}
Abstrak
Jerawat merupakan gangguan pada kulit yang ditandai dengan adanya peradangan yang disertai penyumbatan pada saluran kelenjar minyak dalam kulit yang disebabkan oleh bakteri Propionibacterium acne. Salah satu tanaman obat yang dapat dimanfaatkan sebagai obat jerawat adalah daun sirih. Daun sirih diekstraksi dengan metode maserasi menggunakan pelarut etanol 96\%. Ekstrak dipurifikasi dari klorofilnya dengan metode ekstraksi cair-cair menggunakan pelarut $n$-heksan. Penelitian ini bertujuan untuk mengetahui efek antibakteri terhadap ekstrak etanol daun sirih terpurifikasi dan sediaan krim dengan basis vanishing cream terhadap bakteri $P$. acne dengan metode sumuran. Uji stabilitas fisik sediaan krim meliputi pemeriksaan organoleptis, homogenitas, daya sebar, viskositas, $\mathrm{pH}$, dan tipe $\mathrm{krim} \mathrm{m} / \mathrm{a}$. Hasil penelitian menunjukkan bahwa ekstrak etanol daun sirih terpurifikasi dengan konsentrasi $0,5 \%$ memiliki daya hambat yang lemah, $1 \%$ memiliki daya hambat yang sedang, $1,5 \%$ dan $2 \%$ memiliki daya hambat pertumbuhan $P$. acne yang kuat. Konsentrasi ekstrak dalam pembuatan krim antijerawat dengan basis vanishing cream sebesar 0,5\% memiliki daya hambat yang lemah, $1 \%$ dan $1,5 \%$ memiliki daya hambat yang sedang, $2 \%$ memiliki daya hambat yang kuat sedangkan kontrol positif (asam retinoat) yang digunakan memiliki daya hambat yang kuat terhadap pertumbuhan $P$. acne. Krim antijerawat dengan basis vanishing cream dengan konsentrasi ekstrak $2 \%$ memiliki aktivitas antibakteri yang paling baik terhadap P. acne.
\end{abstract}

Kata kunci: Anti jerawat, daun sirih, krim m/a, Propionibacterium, antibakteri

\section{Pendahuluan}

Kulit merupakan organ terluar penyusun tubuh manusia yang terletak paling luar dan menutupi seluruh permukaan tubuh. Letak paling luar menyebabkan kulit yang pertama kali menerima rangsangan seperti rangsangan sentuhan, rasa sakit, maupun pengaruh buruk dari luar. Hal-hal tersebut menyebabkan kulit rentan terkena penyakit [5].

Salah satu masalah kulit wajah yang sering dijumpai, yaitu timbulnya jerawat. Munculnya jerawat sangat mengganggu penampilan seseorang sehingga akan segera mencari solusi untuk menghilangkan jerawat. Salah satunya penggunaan antibiotik sebagai solusi untuk jerawat yang beberapa dekade ini masih banyak diresepkan. Akan tetapi penggunaan antibiotik sebagai pilihan pertama penyembuhan jerawat harus ditinjau kembali untuk membatasi perkembangan resistensi antibiotik. Saat ini mulai banyak yang memilih back to nature dalam pengobatan jerawat karena efek samping lebih ringan dari pengobatan secara medis [4].

Jerawat atau acne vulgaris adalah kelainan berupa peradangan pada lapisan polisebaseus yang disertai penyumbatan dan penimbunan bahan keratin yang dipicu oleh bakteri Propionibacterium acne, Staphylococcus epidermidis dan Staphylococcus aureus [5]. Bakteri utama penyebab jerawat adalah Propionibacterium acne, karena peningkatan aktivitas androgen pada masa pubertas memicu pertumbuhan kelenjar minyak sebaceous dan peningkatan produksi sebum. Sebum terdiri dari gliserida yang dapat dikonversi menjadi asam lemak bebas dan gliserol oleh lipase yang diproduksi oleh bakteri Propionibacterium acne. Asam lemak bebas tersebut dapat mengiritasi dinding folikular dan menyebabkan peningkatan perombakan sel dan inflamasi [12] Pengobatan jerawat biasanya dilakukan dengan pemberian antibiotik dan bahan-bahan kimia seperti sulfur, resorsinol, asam salisilat, benzoil peroksida, asam azelat, tetrasiklin, eritromisin dan klindamisin. Namun, obat-obatan tersebut juga memiliki efek samping seperti resistensi terhadap antibiotik dan iritasi kulit [5].

Bentuk sediaan kosmetik yang sering digunakan untuk perawatan kulit adalah bentuk sediaan krim (3). Krim adalah sediaan setengah padat yang mengandung air tidak kurang dari $60 \%$ dan dimaksudkan untuk pemakaian luar. Selain itu, krim merupakan bentuk sediaan topikal dengan bentuk setengah padat yang cocok untuk pengobatan jerawat. Penggunaan krim lebih disukai karena krim lebih mudah menyebar dengan rata dan lebih mudah dibersihkan dan dicuci [1].

Vanishing cream merupakan basis krim tipe minyak dalam air yang biasanya mengandung bahan pembasah 
seperti trietanolamine maupun kalium, ammonium dan natrium hidroksida yang dicampurkan dengan asam stearat bebas untuk membentuk emulsi. Basis yang dapat dicuci dengan air seperti Vanishing cream akan membentuk suatu lapisan tipis yang semipermeabel setelah air menguap pada tempat yang digunakan [7]. Basis krim (vanishing cream) disukai pada penggunaan sehari-hari karena memiliki keuntungan yaitu memberikan efek dingin pada kulit, tidak berminyak serta memiliki kemampuan penyebaran yang baik, sehingga sediaan krim dengan basis vanishing cream sangat cocok untuk kulit berjerawat [8].

Pembuatan sediaan kosmetik untuk perawatan kulit wajah dapat menggunakan produk bahan alam sebagai zat aktifnya yang berasal dari ekstrak tumbuhan yang memiliki aktivitas antimikroba yang sangat membantu dalam penyembuhan. Salah satu tanaman yang memiliki kemampuan sebagai antibakteri adalah sirih (Piper betle L.) [6]. Daun sirih dimanfaatkan sebagai obat tradisional untuk mengobati sariawan, batuk, astringent, antiseptik dan antijerawat, yang digunakan dengan cara menghaluskan ataupun merebus daun sirih untuk mengobati bagian yang diperlukan (9).

Ekstrak yang diperoleh dari proses ekstraksi simplisia tanaman obat dengan menggunakan pelarut organik atau air seringkali mengandung senyawa yang tidak diinginkan seperti zat warna (pigmen), karbohidrat, lilin, resin dan sejenisnya. Keberadaan senyawa tersebut seringkali merugikan pada kestabilan dan mengurangi kadar senyawa aktif di dalam ekstrak sehingga harus dihilangkan. Purifikasi ekstrak diharapkan dapat meningkatkan khasiat ekstrak disamping memperkecil jumlah dosisnya. Selain itu, purifikasi ekstrak bertujuan menghilangkan senyawasenyawa pengganggu namun tetap mempertahankan senyawa aktifnya [13].

Kandungan kimia yang diduga terdapat dalam ekstrak terpurifikasi yang memiliki aktivitas antibakteri yaitu kandungan kimia yang bersifat polar seperti flavonoid, tanin, dan polifenol. Tanin merupakan polifenol yang larut dalam air. Mekanisme antibakteri tanin antara lain menghambat enzim ekstraseluler mikroba, menggantikan substrat yang dibutuhkan pada pertumbuhan mikroba, atau bekerja langsung pada metabolisme dengan cara menghambat fosforilasi oksidasi. Flavonoid juga memiliki sifat antibakteri karena dapat menyebabkan terganggunya fungsi dinding sel bakteri melalui mekanisme pembentukan kompleks dengan protein ekstraseluler. Selain kandungan kimia tersebut, daun sirih mengandung juga kavikol dan kavibetol, turunan dari fenol yang mempunyai aktivitas antibakteri dengan cara mendenaturasi protein sel sehingga mengakibatkan terbunuhnya mikroorganisme [14].

Sirih (Piper betle L.) merupakan tumbuhan yang telah lama digunakan dalam pengobatan dan telah terbukti memiliki aktivitas sebagai antibakteri. Ekstrak etanol daun sirih memiliki aktivitas sebagai antibakteri terhadap $P$. acne dan Staphylococcus aureus multiresisten dengan KBM (Kadar Bunuh Minimum) masing-masing sebesar $0,25 \% \mathrm{~b} / \mathrm{v}$ dan $0,5 \% \mathrm{~b} / \mathrm{v}[10]$.

\section{Bahan dan Metode}

\subsection{Preparasi dan Ekstraksi}

Sampel daun sirih (Piper betle L.) diperoleh dari Kecamatan Watopute Kabupaten Muna Provinsi Sulawesi Tenggara. Sampel daun sirih yang sudah tua dikumpulkan, disortasi basah, selanjutnya dicuci dengan air mengalir sampai bersih, ditiriskan, dikeringkan di bawah sinar matahari dan ditutupi kain hitam, disortasi kering, lalu diserbukkan. Maserasi dilakukan terhadap $500 \mathrm{~g}$ serbuk menggunakan 3,5 L etanol (1:7) selama 3x24 jam. Filtrat diperoleh melalui penyaringan dan dipekatkan dengan rotary evaporator dengan suhu $30^{\circ} \mathrm{C}$. Ekstrak kasar lalu dipurifikasi dilakukan dengan melarutkan ekstrak kental menggunakan etanol, kemudian dimasukkan kedalam corong pisah dan ditambahkan $n$-heksana dengan perbandingan pelarut $1: 1$, diekstraksi sampai lapisan nheksana terlihat bening. Ekstrak terpurifikasi yang diperoleh berbentuk ekstrak yang lebih kental berwarna coklat.

\subsection{Skrining Fitokimia}

Skrining fitokimia dilakukan untuk mengetahui kandungan metabolit sekunder antara lain alkaloid, saponin, tannin, dan flavonoid dengan prosedur yang telah ditetapkan $[14,15]$.

\subsection{Uji Aktivitas Antibakteri Ekstrak Terpurifikasi}

Uji aktivitas antibakteri ekstrak etanol daun sirih dapat dilakukan dengan cara memasukkan media agar darah (Blood Agar Base) ke dalam cawan petri sebanyak $10 \mathrm{ml}$ dan dibiarkan hingga memadat sebagai lapisan dasar, setelah memadat dimasukkan lima pencadang secara aseptis ke dalam cawan Petri. Sebanyak $1 \mathrm{~mL}$ suspensi bakteri dicampurkan dengan $15 \mathrm{~mL}$ media agar darah semi padat, dan dimasukkan ke dalam cawan petri sampai memadat. Setelah memadat alat pencadang pada media diangkat secara aseptis hingga membentuk lima sumuran pada media. Pengujian dilakukan dengan menimbang masing-masing ekstrak daun sirih dengan berbagai konsentrasi kemudian dilarutkan menggunakan DMSO 1\% sebanyak $1 \mathrm{~mL}$ hingga larut, kemudian diambil masingmasing sebanyak $20 \mu \mathrm{L}$ dan dimasukkan dalam lubang sumuran dengan berbagai konsentrasi, dan menggunakan DMSO 1\% sebagai kontrol negatif. Media bakteri yang sudah ditetesi bahan antibakteri dimasukkan ke dalam candle jar, kemudian diinkubasi pada suhu $35-37^{\circ} \mathrm{C}$ selama 24 jam. Diameter zona hambatan yang terbentuk diukur menggunakan mistar untuk menentukan aktivitas antibakteri. Zona hambatan diukur dengan mistar dengan cara mengurangi diameter zona bening keseluruhan dengan diameter sumuran. Pengujian dilakukan 3 kali pengulangan [17]. 


\subsection{Formulasi krim}

Tabel 1. Formula krim antijerawat

\begin{tabular}{|c|c|c|c|c|c|c|}
\hline \multirow{2}{*}{ No } & \multirow{2}{*}{ Bahan } & \multicolumn{5}{|c|}{ Formula Krim $(\%$ b/b) } \\
\hline & & F0 & FI & FII & FIII & FIV \\
\hline 1 & $\begin{array}{l}\text { Ekstrak daun } \\
\text { sirih }\end{array}$ & - & 0,5 & 1 & 1,5 & 2 \\
\hline 2 & Asam stearat & 12 & 12 & 12 & 12 & 12 \\
\hline 3 & Setil Alkohol & 2 & 2 & 2 & 2 & 2 \\
\hline 4 & Gliserin & 8 & 8 & 8 & 8 & 8 \\
\hline 5 & Trietanolamin & 3 & 3 & 3 & 3 & 3 \\
\hline 6 & Metil paraben & 0,2 & 0,2 & 0,2 & 0,2 & 0,2 \\
\hline 7 & Propil paraben & 0,05 & 0,05 & 0,05 & 0,05 & 0,05 \\
\hline 8 & Rose Oil & $3 \mathrm{tts}$ & $3 \mathrm{tts}$ & $3 \mathrm{tts}$ & 3 tts & $3 \mathrm{tts}$ \\
\hline 9 & Akuades & $\begin{array}{c}\mathrm{ad} \\
100\end{array}$ & $\begin{array}{c}\mathrm{ad} \\
100\end{array}$ & $\begin{array}{c}\mathrm{ad} \\
100\end{array}$ & $\begin{array}{c}\mathrm{ad} \\
100\end{array}$ & $\begin{array}{c}\mathrm{ad} \\
100\end{array}$ \\
\hline
\end{tabular}

\subsection{Uji Stabilitas Fisik (Cycling Test)}

Uji stabilitas fisik dapat dilakukan dengan menyimpan sampel pada suhu $40^{\circ} \mathrm{C}$ selama 24 jam lalu dipindahkan kedalam oven yang bersuhu $40^{\circ} \mathrm{C}$ selama 24 jam, waktu selama penyimpanan dua suhu tersebut dianggap satu siklus. Uji stabilitas dilakukan sebanyak 6 siklus kemudian diamati ada tidaknya pemisahan fase yang terjadi pada sediaan. Uji stabilitas fisik meliputi pengamatan organoleptis, uji homogenitas, uji viskositas, uji daya sebar, uji pH [18], dan uji tipe krim [19].

\subsection{Uji Aktivitas Krim Terhadap Propionibacterium acne}

Uji aktivitas antibakteri terhadap sediaan krim dapat dilakukan dengan cara memasukkan media agar darah kedalam cawan petri sebanyak $10 \mathrm{~mL}$ dan dibiarkan hingga memadat sebagai lapisan dasar. Sebanyak enam pencadang dimasukkan secara aseptis ke dalam cawan petri, ditambahkan $1 \mathrm{~mL}$ suspensi bakteri ke dalam $15 \mathrm{~mL}$ media agar darah dan dimasukkan ke dalam cawan petri secara aseptis sebagai lapisan semi solidnya sampai memadat. Kemudian dilakukan pengujian dengan cara menimbang masing-masing sebanyak $1 \mathrm{~g}$ sediaan krim F0 (kontrol negatif), F1, F2, F3, dan F4, serta sediaan X (Kontrol positif) dimasukkan dalam lubang sumuran. Media bakteri yang sudah ditetesi bahan antibakteri dimasukkan ke dalam candle jar, kemudian diinkubasi pada suhu $35-37^{\circ} \mathrm{C}$ selama 24 jam. Diameter zona hambat yang terbentuk diukur menggunakan mikrometer untuk menentukan aktivitas antibakteri [17].

\section{Hasil dan Pembahasan}

\subsection{Ekstraksi dan Purifikasi Ekstrak}

Serbuk simplisia daun sirih dari Kabupaten Muna diekstraksi menggunakan etanol 96\%. Hasil ekstraksi disaring kemudian dipekatkan dengan rotary vacuum evaporator pada suhu $30^{\circ} \mathrm{C}$ sehingga diperoleh ekstrak etanol sebanyak 72,4 g (14,48\%). Ekstrak kental kemudian dipurifikasi agar terbebas dari komponen zat ballast. Ekstrak dari proses ekstraksi simplisia dengan pelarut organik atau air, seringkali mengandung senyawa yang tidak diinginkan seperti zat warna (pigment), karbohidrat, lilin, resin dan sejenisnya menjadikan ketidakstabilan sifat fisika ekstrak saat diformulasikan. Keberadaan senyawa atau zat tersebut lebih banyak merugikan pada kestabilan dan mengurangi kadar senyawa aktif di dalam ekstrak sehingga harus dihilangkan [2]. Hasil purifikasi ekstrak sebanyak $20 \mathrm{~g}(4 \%)$.

\subsection{Skrining Fitokimia}

Tabel 2. Hasil uji skrining fitokimia

\begin{tabular}{ccc}
\hline $\begin{array}{c}\text { Jenis } \\
\text { Senyawa }\end{array}$ & Parameter Positif & Hasil \\
\hline Saponin & $\begin{array}{c}\text { Terbentuk busa stabil } \\
\text { selama 15 menit }\end{array}$ & $\begin{array}{c}\text { Terbentuk busa } \\
\text { stabil (Positif) }\end{array}$ \\
\hline Flavonoid & $\begin{array}{c}\text { Terjadi perubahan warna } \\
\text { kuning tua /merah/ } \\
\text { merah-kebiruan/jingga }\end{array}$ & $\begin{array}{c}\text { Perubahan warna } \\
\text { kuning tua } \\
\text { (Positif) }\end{array}$ \\
\hline Tanin & $\begin{array}{c}\text { Terbentuk warna } \\
\text { biru/biru kehitaman/ } \\
\text { hijau kehitaman atau } \\
\text { hitam pekat }\end{array}$ & $\begin{array}{c}\text { Perubahan warna } \\
\text { hijau kehitaman } \\
\text { (Positif) }\end{array}$ \\
\hline Alkaloid & $\begin{array}{c}\text { Terjadi perubahan warna } \\
\text { endapan putih hingga } \\
\text { kekuningan }\end{array}$ & $\begin{array}{c}\text { Perubahan warna } \\
\text { endapan putih } \\
\text { (Positif) }\end{array}$ \\
\hline
\end{tabular}

Senyawa yang terkandung dalam daun sirih meliputi alkaloid, saponin, tannin, dan flavonoid. Mekanisme kerja flavonoid sebagai antimikroba dapat dibagi menjadi 3 yaitu menghambat sintesis asam nukleat, menghambat fungsi membran sel dan menghambat metabolisme energi. Mekanisme antibakteri flavonoid menghambat sintesis asam nukleat adalah cincin A dan B yang memegang peran penting dalam proses ikatan hidrogen dengan menghambat pembentukan DNA dan RNA. Flavonoid menyebabkan terjadinya kerusakan permeabilitas dinding sel bakteri, mikrosom, dan lisosom. Senyawa alkaloid memiliki mekanisme penghambatan dengan cara mengganggu komponen penyusun peptidoglikan pada sel bakteri, sehingga lapisan dinding sel tidak terbentuk secara utuh dan menyebabkan kematian sel tersebut. Tanin diketahui mempunyai aktifitas antiinflamasi, astringen, antidiare, diuretik dan antiseptik. Sedangkan aktivitas farmakologi saponin yang telah dilaporkan antara lain sebagai antiinflamasi, antibiotik, antifungi, antivirus, hepatoprotektor serta antiulcer.

\subsection{Uji Aktivitas Antibakteri Ekstrak Etanol Terpurifikasi}

Uji aktivitas antibakteri ekstrak etanol terpurifikasi daun sirih terhadap $P$. acne dilakukan dengan melihat zona bening yang terbentuk disekitar lubang yang merupakan zona hambat pertumbuhan bakteri. Zona bening yang terlihat dengan masing-masing variasi konsentrasi ekstrak yaitu $0,5 \%, 1 \%, 1,5 \%$, dan $2 \%$ di sekeliling lubang membuktikan bahwa ekstrak etanol terpurifikasi daun sirih memiliki sifat antibakteri terhadap $P$. acne. Konsentrasi 0,5\% merupakan kadar bunuh minimum (KBM) [14]. Kontrol negatif yang digunakan yaitu DMSO karena DMSO banyak digunakan sebagai pelarut ekstrak dan diharapkan tidak memiliki aktivitas. 
Ekstrak etanol terbukti dapat menghambat pertumbuhan bakteri Propionibacterium acne dengan terbentuknya zona bening di sekeliling lubang. Zona bening yang dibentuk merupakan zona hambat bagi pertumbuhan bakteri. Hal ini terjadi karena adanya aktivitas antibakteri pada ekstrak etanol terpurifikasi daun sirih. Hasil uji aktivitas antibakteri ekstrak etanol terpurifikasi daun sirih (Piper Betle L.) dapat dilihat pada Tabel 3.

Tabel 3. Hasil uji aktivitas antibakteri ekstrak

\begin{tabular}{lcc}
\hline \multicolumn{1}{c}{ Sampel } & $\begin{array}{c}\text { Rata-rata diameter } \\
\text { zona hambat }(\mathrm{mm})\end{array}$ & Kategori \\
\hline Ekstrak 0.5\% & 2,33 & Lemah \\
Ekstrak 1 \% & 7,5 & Sedang \\
Ekstrak 1.5\% & 13,25 & Kuat \\
Ekstrak 2\% & 17,33 & Kuat \\
Kontrol (-) & 0 & Tidak Ada \\
\hline
\end{tabular}

Tabel uji aktivitas memperlihatkan ekstrak etanol terpurifikasi daun sirih konsentrasi 0,5\% memiliki tingkat penghambatan terhadap bakteri $P$. acne yang dikategorikan lemah, konsentrasi $1 \%$ tingkat penghambatan termasuk kategori sedang, serta konsentrasi $1,5 \%$ dan $2 \%$ termasuk kategori kuat.

\subsection{Uji Stabilitas Fisik}

Pengujian stabilitas sediaan krim ekstrak etanol daun sirih diantaranya uji organoleptis, uji homogenitas, uji viskositas, uji daya sebar, uji $\mathrm{pH}$, dan uji tipe krim untuk mengetahui kestabilan dan keamanan dari sediaan krim dengan basis vanishing cream yang dihasilkan.

\section{Uji Organoleptis}

Pengamatan organoleptis dilakukan terhadap perubahan-perubahan konsistensi, warna, dan bau sediaan krim. Hasil pengamatan organoleptis dapat dilihat pada Tabel 4.

Tabel 4. Hasil Uji Organoleptik

\begin{tabular}{|c|c|c|c|c|c|c|}
\hline \multirow{2}{*}{ Formula } & \multicolumn{3}{|c|}{ Sebelum Cycling Test } & \multicolumn{3}{|c|}{ Sesudah Cycling Test } \\
\hline & Tekstur & Warna & Aroma & Tekstur & Warna & Aroma \\
\hline F0 & $\begin{array}{l}\text { semi } \\
\text { padat }\end{array}$ & Putih & $\begin{array}{c}\text { Rose } \\
\text { oil }\end{array}$ & $\begin{array}{l}\text { semi } \\
\text { padat }\end{array}$ & Putih & $\begin{array}{c}\text { Rose } \\
\text { oil }\end{array}$ \\
\hline F1 & $\begin{array}{l}\text { semi } \\
\text { padat }\end{array}$ & $\begin{array}{c}\text { coklat } \\
\text { kekuningan }\end{array}$ & $\begin{array}{c}\text { Rose } \\
\text { oil }\end{array}$ & $\begin{array}{l}\text { semi } \\
\text { padat }\end{array}$ & $\begin{array}{c}\text { coklat } \\
\text { kekuningan }\end{array}$ & $\begin{array}{c}\text { Rose } \\
\text { oil }\end{array}$ \\
\hline F2 & $\begin{array}{l}\text { semi } \\
\text { padat }\end{array}$ & $\begin{array}{c}\text { coklat } \\
\text { kekuningan }\end{array}$ & $\begin{array}{c}\text { Rose } \\
\text { oil }\end{array}$ & $\begin{array}{l}\text { semi } \\
\text { padat }\end{array}$ & $\begin{array}{c}\text { coklat } \\
\text { kekuningan }\end{array}$ & $\begin{array}{c}\text { Rose } \\
\text { oil }\end{array}$ \\
\hline F3 & $\begin{array}{l}\text { semi } \\
\text { padat }\end{array}$ & coklat tua & $\begin{array}{c}\text { Rose } \\
\text { oil }\end{array}$ & $\begin{array}{l}\text { semi } \\
\text { padat }\end{array}$ & coklat tua & $\begin{array}{c}\text { Rose } \\
\text { oil }\end{array}$ \\
\hline F4 & $\begin{array}{l}\text { semi } \\
\text { padat }\end{array}$ & coklat tua & $\begin{array}{c}\text { Rose } \\
\text { oil }\end{array}$ & $\begin{array}{l}\text { semi } \\
\text { padat }\end{array}$ & coklat tua & $\begin{array}{c}\text { Rose } \\
\text { oil }\end{array}$ \\
\hline
\end{tabular}

Keterangan:

$\mathrm{F} 0=$ Basis vanishing cream krim

$\mathrm{F} 1=$ Krim dengan konsentrasi ekstrak $0,5 \%$

$\mathrm{F} 2=$ Krim dengan konsentrasi ekstrak $1 \%$

$\mathrm{F} 3=$ Krim dengan konsentrasi ekstrak 1,5\%

$\mathrm{F} 4=$ Krim dengan konsentrasi ekstrak $2 \%$

Hasil pengamatan organoleptis sediaan krim sebelum cycling test memiliki konsistensi semi padat, warna sediaan yaitu F0 berwarna putih, F1 dan F2 berwarna coklat kekuningan, F3 dan F4 berwarna coklat tua, dengan bau khas rose oil. Uji organoleptis sesudah cycling test menunjukkan tidak terjadi perubahan baik pada konsistensi, warna, dan bau. Dapat dikatakan bahwa krim ekstrak daun sirih stabil secara fisik selama proses penyimpanan dipercepat (cycling test).

\section{Uji Organoleptis}

Pemeriksaan homogenitas dilakukan dengan kaca objek. Pengujian dilakukan dengan cara mengoleskan sejumlah krim pada permukaan objek glass untuk melihat homogenitas campuran dari bahan-bahan serta zat aktif yang digunakan dalam formulasi keim. Hasil pengujian homogenitas dapat dilihat pada Tabel 5.

Tabel 5. Hasil Pengujian Homogenitas

\begin{tabular}{ccc}
\hline Formula & Sebelum Cycling Test & Sesudah Cycling Test \\
\hline F0 & Homogen & Homogen \\
F1 & Homogen & Homogen \\
F2 & Homogen & Homogen \\
F3 & Homogen & Homogen \\
F4 & Homogen & Homogen \\
\hline
\end{tabular}

Keterangan:

$\mathrm{F} 0=$ Basis vanishing cream krim

$\mathrm{F} 1=$ Krim dengan konsentrasi ekstrak $0,5 \%$

F2 = Krim dengan konsentrasi ekstrak 1\%

F3 = Krim dengan konsentrasi ekstrak 1,5\%

$\mathrm{F} 4=$ Krim dengan konsentrasi ekstrak $2 \%$

Hasil yang diperoleh sebelum dan sesudah cycling test menunjukkan susunan yang homogen dan tidak terlihat butiran kasar. Krim pada penelitian kali ini memenuhi syarat karena homogen dan tidak ditemukan partikel kasar.

\section{Uji Viskositas}

Viskositas merupakan gambaran dari tahanan suatu benda cair untuk mengalir. Sifat ini sangat penting dalam formulasi sediaan cair dan semipadat karena sifat ini menentukan sifat dari sediaan dalam hal campuran dan sifat alirnya, baik pada saat diproduksi, dimasukkan ke dalam kemasan, serta sifat-sifat penting pada saat pemakaian, seperti konsistensi, daya sebar, dan kelembaban. Hasil uji viskositas sediaan krim dapat dilihat pada Gambar 1.

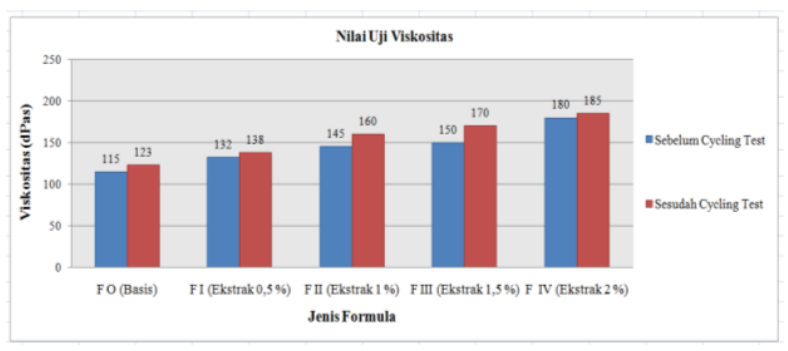

Gambar 1. Hasil uji viskositas

Viskositas akan meningkat seiring dengan peningkatan konsentrasi ekstrak baik sebelum dan setelah cycling test dilakukan. Ekstrak yang ditambahkan kedalam basis krim berupa ekstrak kental, sehingga semakin besar konsentrasi ekstrak, maka viskositasnya meningkat. 
Selain ekstrak, setil alkohol juga mampu meningkatkan viskositas sediaan. Meningkatnya viskositas dapat menyebabkan sifat dan stabilitas krim semakin baik sehingga krim dapat melekat pada kulit lebih lama. Dalam beberapa siklus selama cycling test, formula krim ditempatkan pada suhu $40^{\circ} \mathrm{C}$ yang memungkinkan terbentuknya uap air selama cycling test. Dengan terbentuknya uap air menunjukkan bahwa air dalam sediaan mengalami penguapan sehingga kadar air dalam sediaan menjadi berkurang. Berkurangnya kadar air dalam sediaan akan menunjukkan peningkatan viskositas, namun viskositas masih memenuhi nilai viskositas yang diinginkan, yaitu 50 - $200 \mathrm{dPa}$.

\section{Uji Daya Sebar}

Uji daya sebar dilakukan untuk mengetahui daya sebar yang dapat ditempuh sediaan krim yang dibuat. Hasil uji daya sebar sediaan krim dapat dilihat pada Gambar 2.

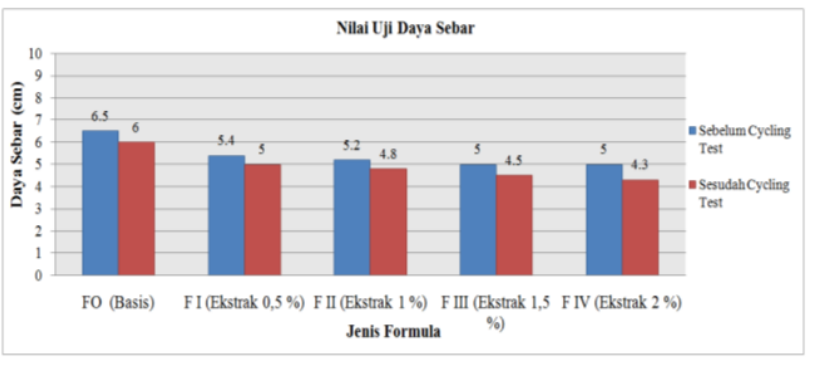

Gambar 2. Hasil uji daya sebar

Daya sebar dipengaruhi oleh viskositas sediaan. Semakin tinggi viskositas krim maka tahanan yang dimiliki pun semakin besar sehingga krim semakin sukar untuk mengalir dan daya menyebarnya menjadi semakin kecil. Hal ini sesuai dengan hasil yang diperoleh bahwa, nilai viskositas berbanding terbalik dengan daya sebar.

\section{Uji pH Sediaan}

Uji $\mathrm{pH}$ merupakan parameter fisikokimia yang harus diuji pada sediaan topikal, karena $\mathrm{pH}$ mempengaruhi efektivitas, stabilitas, dan kenyamanan pengguna sediaan. Sediaan bersifat basa (tidak termasuk dalam rentang $\mathrm{pH}$ kulit (4-7) akan mengakibatkan kulit terasa licin, cepat kering, serta dapat mempengaruhi elastistas kulit, namun apabila sediaan bersifat asam dengan rentang $\mathrm{pH}$ di bawah rentang $\mathrm{pH}$ kulit akan mengakibatkan mudah mengalami iritasi.

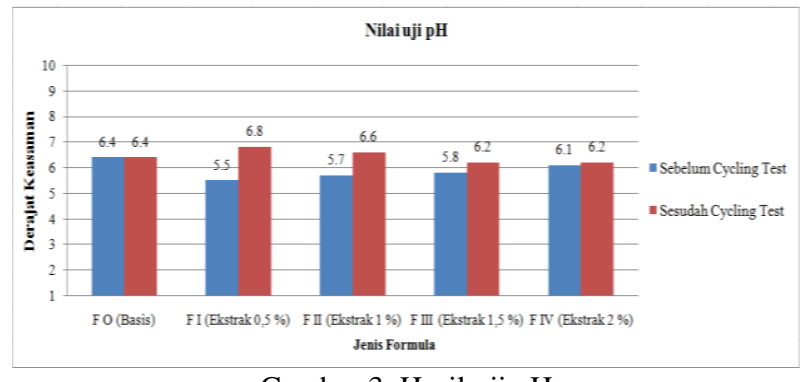

Gambar 3. Hasil uji pH
Hasil yang diperoleh menunjukkan bahwa $\mathrm{pH}$ sediaan krim dengan konsentrasi $0 \%$ (basis) yang tidak mengandung ekstrak etanol daun sirih tetap baik sebelum cycling test maupun sesudah cycling test sehingga dapat dikatakan tidak ada reaksi yang terjadi pada bahan-bahan tambahan. Sediaan krim yang mengandung ekstrak etanol daun sirih sebelum cycling test menunjukkan perubahan nilai $\mathrm{pH}$ setelah ditambahkan ekstrak. Semakin besar konsentrasi ekstrak yang ditambahkan maka $\mathrm{pH}$ sediaan yang diperoleh semakin asam sehingga mempengaruhi nilai $\mathrm{pH}$ sediaan krim. Sedangkan setelah cycling test $\mathrm{pH}$ sediaan mengalami penurunan, hal ini kemungkinan disebabkan karena adanya pengaruh hidrolisis dari senyawa yang dikandung ekstrak pada sediaan krim, semakin sedikit $\mathrm{OH}^{-}$dalam suatu sediaan maka nilai $\mathrm{pH}$ sediaan akan cenderung turun. Meskipun mengalami perubahan, nilai $\mathrm{pH}$ masih masuk dalam rentang yang ideal bagi kulit. Nilai $\mathrm{pH}$ sediaan yang ideal harus sesuai dengan $\mathrm{pH}$ kulit yaitu 4,5-7,0.

\section{Uji Tipe Krim m/a}

Krim adalah bentuk sediaan setengah padat berupa emulsi yang mengandung satu atau lebih bahan obat terlarut atau terdispersi dalam bahan dasar yang sesuai. Krim terdiri dari emulsi minyak dalam air atau disperse mikrokristal asam lemak atau alkohol berantai panjang dalam air, yang dapat dicuci dengan air dan lebih ditujukan untuk pemakaian kosmetika dan estetika. Hasil yang diperoleh bahwa krim tipe minyak dalam air baik sebelum dan sesudah cycling test, jika dilarutkan dengan menggunakan air terjadi kestabilan dimana air akan terdispersi dalam media, tetapi jika dilarutkan dengan minyak krim akan pecah dimana air dan minyak tidak akan tercampur satu sama lain. Minyak dalam air dapat dengan mudah dilarutkan menggunakan pelarut air, sebaliknya tipe krim air dalam minyak dapat larut dengan cairan minyak. Hasil yang diperoleh krim dengan basis vanishing cream ekstrak terpurifikasi daun sirih baik sebelum cycling test maupun sesudah cycling test memiliki tipe krim minyak dalam air.

\subsection{Uji aktivitas krim terhadap Propionibacterium acne}

Uji aktivitas krim dengan basis vanishing cream terhadap Propionibacterium acne dilakukan dengan metode sumur (difusi agar) yang didasarkan pada kemampuan senyawa-senyawa antibakteri yang diuji untuk menghasilkan diameter zona penghambatan di sekeliling sumur uji terhadap bakteri yang digunakan sebagai penguji. Pengujian aktivitas antibakteri sediaan dilakukan pada masing-masing formula dimana F0 sebagai kontrol negatif, F1, F2, F3 dan F4 serta sediaan krim yang mengandung asam retinoat sebagai kontrol positif. Formula F0 merupakan formula tanpa ekstrak diharapkan tidak terbentuk zona bening sehingga dapat dinyatakan bahwa bahan tambahan formulasi tidak mempunyai aktivitas antibakteri tetapi mempengaruhi aktivitas ekstrak, terlihat bahwa bahan tambahan mempengaruhi aktivitas karena pada konsentrasi yang sama zona hambat yang dihasilkan 
pada sediaan lebih kecil dibandingkan dengan ekstrak, karena sediaan krim menghambat pelepasan kandungan senyawa aktif dari ekstrak untuk berdifusi kedalam media, sehingga ekstrak yang terkandung dalam sediaan tidak terlepas sempurna dalam media. Sehingga aktivitas sediaan yang dihasilkan lebih rendah dibandingkan aktivitas ekstrak. Hasil uji aktivitas antibakteri krim ekstrak daun sirih dapat dilihat pada Tabel 5.

Tabel 5. Hasil uji aktivitas krim Ekstrak Daun Sirih

\begin{tabular}{ccc}
\hline Perlakuan & $\begin{array}{c}\text { Rata-rata diameter zona } \\
\text { hambat }(\mathbf{m m})\end{array}$ & Kategori \\
\hline Krim F0 (K-) & 0 & Tidak ada \\
Krim F1 & 1,41 & Lemah \\
Krim F2 & 5,33 & Sedang \\
Krim F3 & 9,58 & Sedang \\
Krim F4 & 13 & Kuat \\
Kontrol (+) & 17,75 & Kuat \\
\hline
\end{tabular}

\section{Keterangan:}

Kontrol $(\mathrm{K}+)=$ Krim Asam Retinoat

Krim F0 (K-) = Formula tanpa ekstrak

Krim F1 = Formula konsentrasi ekstrak $0.5 \%$

Krim F2 = Formula konsentrasi ekstrak $1 \%$

Krim F3 = Formula konsentrasi ekstrak $1.5 \%$

Krim F4 = Formula konsentrasi ekstrak $2 \%$

Uji aktivitas antibakteri sediaan diperoleh hasil yaitu pada krim F1 dan F2 memiliki daya hambat pertumbuhan yang sedang dengan diameter zona bening $6,25 \mathrm{~mm}$ dan 10,41 mm. Sedangkan F3 dan F4 memiliki daya hambat pertumbuhan yang kuat dengan diameter zona bening berturut-turut yaitu 14,33 mm dan 16,41 mm, serta kontrol positif memiliki daya hambat pertumbuhan yang kuat dengan diameter zona bening 19,75 mm. Sedangkan F0 tidak memiliki daya hambat pertumbuhannya yang berarti F0 (kontrol negatif) tidak mempengaruhi daya hambat pertumbuhan ekstrak setelah diformulasi menjadi sediaan krim

\section{Kesimpulan}

Sediaan krim ekstrak terpurifikasi daun sirih dengan konsentrasi $0,5 \%, 1 \%, 1,5 \%$, dan $2 \%$ memiliki aktivitas antijerawat dengan nilai daya hambat masing-masing zona hambat 1,41 mm; 5,33 $\mathrm{mm} ; 9,58 \mathrm{~mm}$; dan $13 \mathrm{~mm}$ terhadap bakteri $P$. acne. Formula sediaan krim ekstrak terpurifikasi daun sirih stabil secara fisik selama penyimpanan ditinjau dari pengamatan organoleptis, homogenitas, $\mathrm{pH}$, viskositas, daya sebar, dan tipe krim m/a.

\section{Daftar Pustaka}

1. Atmoko AD, Anom P. Formulasi Bentuk Sediaan Krim Ekstrak Daun Sirih (Piper Betle Linn) Hasil Isolasi Metode Maserasi Etanol 90\%, Indonesian Journal on Medical Science, 2014, 1(2).

2. Awwalita F. Uji Aktivitas Antibakteri Ekstrak Etanol Total dan Ekstrak Etanol Terpurifikasi Daun Binahong (Anredera cordifolia (Ten.) Steenis) terhadap Staphylococcus aureus Resisten, Skripsi, Universitas Negeri Jember, 2016.

3. Fitriansyah SN, Dolih G. Formulasi Dan Evaluasi Fisik Sediaan Krim Pelembab Dimethylsilanol Hyaluronate
Dengan Penambahan Basis Nano Dan Fase Minyak Kelapa Murni, Indonesian Journal of Pharmaceutical Science and Technology, 2014, 3(1).

4. Ismiyati N, Trilestari. Pengembangan Formulasi Masker Ekstrak Air Daun Alpukat (Persea Americana Mill) Sebagai Antibakteri Staphylococcus Aureus Untuk Pengobatan Jerawat, Medula, 2014, 2(1).

5. Kumesan YAN, Paulina VYY, Hamidah SS. Formulasi Dan Uji Aktivitas Gel Antijerawat Ekstrak Umbi Bakung (Crinum Asiaticum L.) Terhadap Bakteri Staphylococcus Aureus Secara In Vitro, Jurnal Ilmiah Farmasi, 2013, 2(2).

6. Kursia S, Julianri SL, Burhanuddin T, Asril B, Rahim, Nursamsiar. Uji Aktivitas Antibakteri Ekstrak Etilasetat Daun Sirih Hijau (Piper betle L.) terhadap Bakteri Staphylococcus epidermidis, Indonesian Journal of Pharmaceutical Science and Technology, 2016, 3(2).

7. Lachman L, Herbert AL, Joseph LK. Teori dan Praktek Farmasi Industri, $3^{\text {rd }}$ Ed, Jakarta: UI Press, 1994.

8. Lucyani N. Uji Efektivitas Antibakteri Sediaan Krim Tipe m/a Dari Minyak Atsiri Kulit Buah Jeruk Pontianak (Citrus Nobilis Lour. Var. Microcarpa) Terhadap Isolat Propionibacterium acnes Secara In vitro, Naskah Pubikasi Universitas Tanjungpura, Pontianak, 2014.

9. Noventi W, Novita C. Potensi Ekstrak Daun Sirih Hijau (Piper betle L.) Sebagai Alternatif Terapi Acne vulgaris, Majority, 2016, 5(1).

10. Putri ZF. Uji Aktivitas Antibakteri Ekstrak Etanol Daun Sirih (Piper betle L.) Terhadap Propionibacterium acne dan Staphylococcus aureus Multiresisten, Skripsi, UNS, 2010.

11. Rivai H, Putri EN, Humaira F. Pembuatan dan Karakterisasi Ekstrak Kering Daun Sirih Hijau (Piper betle L.), Higea, 2014, 6(2).

12. Sukandar EY, Retnosari A, Sigit JI, Adnyana IK, Setiadi, AP, Anggadireja A. ISO Farmakoterapi 2. Jakarta: Penerbit ISFI, 2011.

13. Warditiani NK, Larasanty, LPF, Widjaja INK, Juniari NPM, Nugroho AE, Pramono S. Identifikasi Kandungan Kimia Ekstrak Terpurifikasi Herba Sambiloto, Jurnal Farmasi Udayana, 2014, 3(1); 22-25.

14. Widyaningtias NMR, Yustiantara PS, Paramita NLPV. Uji Aktivitas Antibakteri Ekstrak Terpurifikasi Daun sirih hijau (Piper betle L.) Terhadap Bakteri Propionibacterium acnes. Jurnal Farmasi Udayana, 2014, 3(1); 50-53.

15. Harborne JB. Metode Fitokimia: Penuntun Cara Modern Menganalisis Tumbuhan. Terjemahan Padmawinata K dan Soediro I. Bandung: Penerbit ITB, 1987

16. Nuralifah N, Jabbar A, Parawansah P, Iko RA. Uji Toksisitas Akut Ekstrak Etanol Daun Notika (Archboldiodendron calosercium (Kobuski)) Terhadap Larva Artemia salina Leach dengan Menggunakan Metode Brine Shrimp Lethality Test (BSLT). Pharmauho, 2018, 4(2);1-5

17. Rahmi HA, Cahyanto T, Sujarwo T, Lestari RI. Uji Aktivitas Antibakteri Ekstrak Daun Beluntas (Pluchea indica (L.) Less.) Terhadap Propionibacterium acnes Penyebab Jerawat, JURNAL ISTEK, 2015, 9(1)

18. Wijayanti NPAD, Astuti KW, Prasetia IGNJA, Darayanthi MYD, Nesa PNPD, Wedarini LDS, Adhiningrat DNP. Profil Stabilitas Fisika Kimiamasker Gel Peel-Off Ekstrak Kulit Buah Manggis (Garcinia Mangostana L.), Skripsi, Universitas Udayana, 2015.

19. Shovyana HH, Zulkarnain AK. Physical Stability and Activity of Cream W/O Etanolic Fruit Extract of Mahkota Dewa (Phaleria macrocarpha (Scheff.) Boerl,) as a sunscreen. Traditional Medicine Journal, 2013, 18(2) 